\title{
PENGARUH EKSTRAK METANOL DAUN SIRSAK (Annona muricata Linn.) TERHADAP VIABILITAS GALUR SEL KANKER PROSTAT
}

\author{
Retno Yulianti ${ }^{1}$, Ria Kodariah², Puspita Ekawuyung ${ }^{2}$
}

\begin{abstract}
Abstrak
Daun sirsak mengandung senyawa aktif annonaceous acetogenins yang memiliki efek sitotoksik pada sel kanker. Penelitian ini bertujuan untuk mengetahui pengaruh ekstrak daun sirsak terhadap viabilitas dan peningkatan daya hambat terhadap galur sel kanker prostat PC3. Desain penelitian adalah eksperimental in vitro. Subyek penelitian adalah cell line PC3 yang terbagi 5 kelompok yaitu kelompok kontrol sel, kelompok perlakuan dengan ekstrak metanol daun sirsak (EMDS) dengan konsentrasi 6,25; 12,5 dan $25 \mathrm{mg} / \mathrm{mL}$ dan kelompok doksorubisin. Kelompok perlakuan diuji viabilitas sel dengan MTT assay pada inkubasi 0 dan 24 jam dan dilakukan pengamatan morfologi sel. Data dianalisis dengan uji statistik ANOVA. Hasil penelitian menunjukkan penurunan nilai OD pada kelompok EMDS 6,25 dan 12,5 ug/mL, namun uji statistik tidak berbeda bermakna dan kemampuan menghambat viabilitas sel paling besar ada pada kelompok EMDS 12,5 ug/mL (nilai OD 0,94). Pengamatan morfologi sel menunjukkan efek sitotoksik. Kesimpulan: Ekstrak metanol daun sirsak memiliki peran potensial sebagai antikanker terhadap galur sel kanker prostat PC3 meskipun sangat kecil efek penghambatannya.
\end{abstract}

Kata kunci: ekstrak metanol daun sirsak, viabilitas sel, sel kanker PC3.

\begin{abstract}
Soursop leaves contain annonaceous acetogenins active compounds that have a cytotoxic effect on cancer cells. The aim of this study is to determine the effect of soursop leaf extract on the viability and inhibitory rate on the prostate cancer cell line PC3. The study was an experimental in vitro study. Subjects were 5 groups of PC3 cell line: cell control group, the group treated with methanol extract of soursop leaves (EMDS) with the concentrations of 6.25; 12.5 and $25 \mathrm{mg} / \mathrm{mL}$ and the doxorubicin group. The groups were tested using the MTT cell viability assay at 0 and 24 hours of incubation followed by PC3 cell morphology examination. Data were analyzed by ANOVA test. The results showed a decrease in the OD value of 6.25 and $12.5 \mathrm{ug} / \mathrm{mL} E M D S$ group, but statistical tests did not differ significantly and the EMDS $12.5 \mathrm{mg} / \mathrm{mL}$ group showed the highest ability in inhibiting cell viability (OD 0.94). Observation of cell morphology showed cytotoxic effects. Conclusion: The methanol extract of soursop leaf has a potential as an anticancer against prostate cancer cell lines despite the very small inhibitory effect.
\end{abstract}

Keywords: methanol extract of soursop leaves, cell viability, PC3 cancer cells

Afiliasi Penulis : 1.Departemen Patologi Anatomi FK Universitas Pembangunan Nasional “Veteran”. 2. Departemen Patologi Anatomi FK Universitas Indonesia Korespondensi: Retno Yulianti,Departemen Patologi Anatomi FK Universitas Pembangunan Nasional “Veteran”, email : dr.retnoyulianti@yahoo.com 


\section{PENDAHULUAN}

Saat ini permasalahan angka kematian akibat kanker semakin meningkat. Penyakit kanker menjadi penyebab kematian nomor dua di dunia. Berdasarkan data Cancer Research UK dan GLOBOCAN tahun 2008 diperkirakan penyakit kanker terjadi hampir 12,7 juta kasus baru dan angka kematian tercatat sebesar 7,6 juta $(13 \%)^{1,2}$, sedangkan prevalensi kanker di Indonesia mencapai 4.3 per 1.000 orang (sekitar 12 juta) pertahun. ${ }^{3}$ Salah satu kanker yang sering didiagnosis pada pria adalah kanker prostat. Data dunia menyebutkan bahwa angka kejadian kanker prostat mencapai sekitar 899.000 (13,6\%), sedangkan angka kematiannya tercatat sebesar $258.000(6,1 \%){ }^{2}$ Di Indonesia, insiden kanker prostat selama periode Januari 1995 hingga Desember 2007 menurut data Rumah Sakit Cipto Mangunkusumo dan Rumah Sakit Kanker Dharmais terdapat 610 kasus kanker prostat dan terjadi peningkatan hampir tiga kali lipat. ${ }^{4}$

Kanker merupakan penyakit multikompleks yang dapat merusak banyak fungsi sel dan mempunyai kemampuan untuk tumbuh cepat dan tidak terkendali serta mampu bermetastasis ke jaringan tubuh lain yang jauh dari tempat asalnya. ${ }^{5}$ Efek samping dan efek resistensi tubuh terhadap obat kemoterapi serta biaya pengobatan yang mahal menjadikan alasan yang mendorong pasien mencari pengobatan alternatif seperti obat herbal. Masyarakat masih menganggap obat herbal tidak memiliki efek samping yang merugikan, mudah didapat dan cukup murah dibandingkan dengan obat modern. ${ }^{6}$ Bahkan WHO sejak tahun 2002 membuat suatu strategi dalam pengobatan tradisional. $^{7}$

Indonesia sebagai negara yang kaya akan sumber bahan nabati alami masih belum sepenuhnya dapat menggali dan memanfaatkan bahan obatobatan alami terutama untuk mengatasi penyakit kanker. Sehingga perlu dieksploitasi tumbuh-tumbuhan yang ada terutama di pekarangan rumah sebagai obat tradisional, meskipun secara turun temurun masyarakat kita sudah memakai tanaman obat yang dikenal dengan jamu untuk mengatasi berbagai penyakit.

Salah satu bahan alam yang memiliki potensi sebagai obat tradisional (herbal) adalah daun sirsak. Daun sirsak (Annona muricata Linn.) merupakan salah satu tanaman dari family Annonaceae. Beberapa uji fitokimia yang telah dilakukan ternyata daun sirsak mengandung senyawa kimia antara lain alkaloid, karbohidrat, glikosida, saponin, tanin, phytosterol, terpenoid, flavonoid, minyak esensial dan annonaceous acetogenins. ${ }^{8}$ Manfaat dari senyawa yang terkandung dalam tanaman sirsak terutama daunnya dapat digunakan untuk pestisida, antimikroba, antiparasit, antiprotozoal, pengobatan untuk asma, sakit kepala, hipertensi, batuk dan sedatif, antioksidan dan bahkan beberapa senyawa aktif daun sirsak memiliki sitotoksisitas terhadap sel kanker seperti kanker hati, galur sel kanker ovarium, payudara, kandung kemih dan kulit pada dosis yang rendah $\left(\mathrm{IC}_{50}<4 \mathrm{ug} / \mathrm{mL}\right) .{ }^{9,10}$

Efek sitotoksik asetogenin dengan cara bekerja di kompleks I rantai transport elektron melalui penghambatan $\mathrm{NADH}$-ubiquinon oksidoreduktase di mitokondria sebagai organ tempat dihasilkannya energi dalam bentuk ATP. 
Sel-sel kanker sangat membutuhkan energi dalam bentuk ATP untuk memperbanyak diri, namun akibat efek aktivitas asetogenin sel kanker kekurangan sumber energi sehingga proses proliferasi berhenti dan selanjutnya sel kanker mengalami kematian sel. ${ }^{11,12}$ Meskipun memiliki efek sitotoksik, namun asetogenin bekerja secara selektif hanya menyerang sel yang abnormal dengan energi yang besar untuk pertumbuhannya. ${ }^{10}$

Salah satu turunan annonaceous acetogenin seperti Annonacin memiliki kemampuan menahan siklus sel pada fase $\mathrm{G}_{1}$ dan menghambat masuknya sel ke dalam fase $S$ dengan menginduksi p21, Bax dan Bad pada galur sel kanker kandung kemih T24. ${ }^{10}$

Pamungkas AR. membuktikan bahwa ekstrak metanol daun sirsak memiliki efek sitotoksik dan mampu menginduksi apoptosis pada galur sel kanker payudara T47D dengan konsentrasi IC50 sebesar $46,194 \mu \mathrm{g} / \mathrm{mL} .{ }^{13}$

Dari penelitian-penelitian tersebut, meskipun pendekatan secara empiris ekstrak daun sirsak (Annona muricata L.) dipercaya berpotensi sebagai antikanker pada manusia, namun potensi yang dimiliki daun sirsak sebagai antikanker masih akan terus dikembangkan agar didapatkan informasi ilmiah yang akurat terutama untuk pengobatan kanker prostat.

\section{METODE}

Penelitian ini adalah penelitian eksperimental laboratorik in vitro menggunakan rancangan post test control group only design. Pelaksanaan penelitian meliputi beberapa tahap kegiatan, yaitu kultur galur sel kanker prostat PC3, persiapan konsentrasi ekstrak metanol daun sirsak (Annona muricata L.), uji sitotoksisitas MTT assay dan analisis data.

Subjek penelitian adalah galur sel kanker prostat PC3 yang didapatkan dari SCl KalGen, PT Kalbe dan dikelompokkan menjadi 5 kelompok yaitu kelompok kontrol positif (doksorubisin), kontrol sel (kontrol negatif) dan kelompok perlakuan yang diberi ekstrak metanol daun sirsak (Annona muricata L.) dengan konsentra-si bertingkat yaitu 6,25; 12,5 dan $25 \mu \mathrm{g} / \mathrm{mL}$.

Bahan tanaman yang digunakan adalah ekstrak metanol daun sirsak (Annona muricata Linn.) yang diperoleh dari Laboratorium Farmasi Universitas Soedirman, Purwokerto. Ekstrak metanol daun sirsak dilarutkan hingga diperoleh larutan stok $5 \mathrm{mg} / \mathrm{mL}$ kemudian dilarutan dengan RPMI dengan cara pengenceran hingga didapatkan konsentrasi 6,25;12,5 dan $25 \mu \mathrm{g} / \mathrm{mL}$.

Galur sel kanker prostat PC3 dikultur di Laboratorium Oral Biology Fakultas Kedokteran Gigi Universitas Indonesia, Jakarta sebagai monolayer adherent di dalam medium RPMI 1640, FBS $10 \% \quad v / v$ dan $1 \%$ penisilinstreptomisin. Sel diinkubasi dalam inkubator suhu $37^{\circ} \mathrm{C}, 5 \% \mathrm{CO}_{2}$. Subkultur dilakukan apabila sel mencapai konfluen $90 \%$. Medium lama dalam flask kultur dibuang dan sel dibilas dengan RPMI, lalu EDTA dan tripsin 0,025\% 3cc kemudian diinkubasi selama 2 menit dalam inkubator pada suhu $37^{\circ} \mathrm{C} 5 \%$ $\mathrm{CO}_{2}$, ambil suspensi sel dan masukkan ke dalam tabung steril $15 \mathrm{ml}$ untuk disentrifugasi pada kecepatan 1200 rpm 10 menit. Setelah supernatan dibuang, dilakukan penambahan media partum- 
buhan baru, kemudian dibagikan ke dalam beberapa flask kultur. ${ }^{14}$

Uji sitotoksisitas dilakukan dengan cara: sel PC3 yang sudah dipanen, selanjutnya dihitung dengan haemositometer lalu dimasukkan ke dalam 96 well plate yang berisi medium lengkap dengan kepadatan 20.000/well sebanyak $100 \mu \mathrm{L} /$ well. Kemudian diinkubasi selama 24 jam. Selanjutnya dilakukan starvasi dengan medium RPMI 1640, FBS $1 \%$ dan penisilin-streptomisin $1 \%$ selama 24 jam. Setelah inkubasi selesai masukkan ekstrak metanol daun sirsak dengan konsentrasi 6,$25 ; 12,5$ dan 25 $\mu \mathrm{g} / \mathrm{mL}$ dan doksorubisin $15 \mu \mathrm{g} / \mathrm{mL}$ sebagai kontrol positif sebanyak $100 \mu \mathrm{L}$ lalu inkubasi kembali selama 24 jam. Setelah masa inkubasi selesai, dilihat hasilnya dan difoto. Selanjutnya supernatan dibuang lalu ditambahkan MTT dengan konsentrasi $0,5 \mathrm{mg} / \mathrm{mL}$ dalam PBS dimasukkan ke masingmasing well sebanyak $100 \mu \mathrm{L}$. Kemudian diinkubasi selama 4 jam pada inkubator $5 \%$ CO2 pada suhu $37^{\circ} \mathrm{C}$. Lalu ditambah stop solution sebanyak $100 \mu \mathrm{L}$. Stop solution adalah larutan $\mathrm{HCl} 0,04 \mathrm{~N}$ dalam isopropanol. Kemudian diinkubasi pada suhu kamar selama 1-2 jam dan absorbansi dibaca pada serapan $595 \mathrm{~nm}$ dengan Elisa reader. ${ }^{15}$ Dilakukan juga pada kontrol sel dan kontrol media.Setiap pengujian dilakukan duplo.

Data yang diperoleh sebelum dianalisa lebih lanjut akan diuji normalitasnya dengan uji KolmogorovSmirnov dan homogenitasnya dengan uji Levene. Untuk mengetahui pengaruh pemberian ekstrak metanol daun sirsak terhadap galur sel kanker prostat PC3 dilakukan uji one way Anova dilanjutkan uji $t$-dependen namun jika data tidak berdistribusi normal dan homogen maka analisa dilakukan dengan uji Kruskal Wallis untuk membandingkan data lebih dari dua sampel yang dilanjutkan dengan uji Mann Whitney untuk mengetahui perbedaan antara data kelompok kontrol dengan data kelompok perlakuan. Pada penelitian ini menggunakan interval kepercayaan $95 \%$ dan $p<0,05 .^{16}$

\section{HASIL DAN PEMBAHASAN}

Untuk mendeteksi adanya aktivitas antineoplastik dari suatu senyawa ekstrak metanol daun sirsak (Annona muricata Linn.) maka dilakukan uji kolorimetris kuantitatif untuk proliferasi sel (viabilitas sel) yaitu menggunakan metode tidak langsung MTT assay. Prinsip MTT memperlihatkan aktivitas metabolik di mitokondria sel hidup, yang tergantung pada reduksi garam tetrazolium MTT oleh enzim suksinat dehidrogenase mitokondria sel viable, untuk membentuk produk formazan ungu yang jumlahnya setara dengan jumlah sel hidup yang terdapat dalam kultur. ${ }^{15}$ Artinya, intensitas warna ungu yang terbentuk ini berkorelasi secara langsung dengan jumlah sel yang aktif melakukan metabolisme, dengan demikian berkorelasi langsung dengan jumlah sel yang hidup. Pengukuran sel hidup yang didapat berupa nilai rerata optical density (OD) dari masing-masing kelompok.

Pada penelitian ini dilakukan perlakuan terhadap ekstrak metanol daun sirsak dengan konsentrasi 6,25; 12,5 dan $25 \mu \mathrm{g} / \mathrm{mL}$ pada kultur galur sel kanker prostat PC3 dibandingkan dengan kontrol tanpa perlakuan dan kontrol positif menggunakan doxorubisin. Diperoleh hasil nilai absorbansi untuk menghitung persentase viabilitas galur sel kanker prostat PC3 yang tersaji pada 
Tabel.1. Untuk mengetahui pengaruh EMDS yang diberikan terhadap viabilitas sel PC3 maka penghitungan dilakukan terhadap nilai OD setelah waktu inkubasi 24 jam.

Pertumbuhan dan pembelahan sel merupakan hal penting dalam masalah kanker, karena kanker merupakan penyakit yang menunjukkan adanya pembelahan sel yang tidak terkendali. ${ }^{5}$ Pembelahan sel terjadi dalam urutan peristiwa yang dikenal dengan siklus pembelahan sel atau siklus sel. Umumnya untuk menyelesaikan satu siklus pembelahan diperlukan 12 jam sampai 24 jam. $^{17}$ Waktu ini dikenal dengan kecepatan pembelahan sel. Penelitian ini mengidentifikasi pembelahan/proliferasi sel PC3 terjadi sesudah 24 jam, hal ini sesuai dengan sifat sel PC3 yang memiliki doubling time selama 25 jam, sehingga waktu 24 jam diharapkan dapat melihat efek antineoplastik dari senyawa aktif ekstrak metanol daun sirsak terhadap sel PC3. ${ }^{18}$ Ini sesuai dengan penelitian yang dilakukan oleh Yuan dkk ${ }^{19}$ menunjukkan bahwa dalam 24 jam sudah terjadi penurunan ketahanan hidup sel kanker kandung kemih T24 yang diinkubasi dengan asetogenin squamocin dan annonacin dari akar Annona retikulata. Ini membuktikan senyawa aktif asetogenin bersifat sitotoksik terhadap sel kanker dengan kemampuannya menghambat pembelahan/proliferasi sel pada fase $\mathrm{G}_{1}$ dan meningkatkan apoptosis dengan meningkatkan ekspresi proapoptosis Bax dan Bad serta p21.

Dari data OD 24 jam yang didapatkan dilakukan analisis statistik ANOVA dan dilanjutkan dengan analisis Posthoc untuk mengetahui apakah terdapat nilai rerata absorbansi yang berbeda diantara masing-masing kelompok perlakuan.

Tabel 1. Profil Aktivitas Ekstrak Metanol Daun Sirsak Terhadap \% Sel Hidup Sel PC3 pada Inkubasi 0 dan 24 Jam

\begin{tabular}{cccccccccccccc}
\hline $\begin{array}{c}\text { No } \\
\text { Ulangan }\end{array}$ & \multicolumn{4}{c}{ O Jam } & & & \multicolumn{5}{c}{$\mathbf{2 4}$ jam } \\
& Med & K(-) & EMDS & EMDS & EMDS & Doxo & Med & K(-) & EMDS & EMDS & EMDS & Doxo \\
& & & 6,25 & 12,5 & 25 & & & & 6,25 & 12,5 & 25 & \\
\hline $\mathbf{1}$ & 0.09 & 0.18 & 0.2 & 0.14 & 0.29 & 0.2 & 0.11 & 0.28 & 0.26 & 0.29 & 0.26 & 0.22 \\
$\mathbf{2}$ & 0.33 & 0.97 & 0.7 & 1.37 & 0.74 & 0.76 & 0.33 & 1.17 & 0.81 & 1.12 & 1.2 & 1.01 \\
$\mathbf{3}$ & 0.05 & 0.15 & 0.2 & 0.18 & 0.12 & 0.18 & 0.21 & 0.82 & 0.96 & 0.9 & 0.65 & 0.86 \\
$\mathbf{4}$ & 0.21 & 0.37 & 0.31 & 0.54 & 0.24 & 0.23 & 0.67 & 0.82 & 1.06 & 0.51 & 0.94 & 0.67 \\
$\mathbf{5}$ & 0.56 & 0.77 & 0.78 & 0.73 & 0.81 & 0.83 & 0.67 & 0.82 & 0.61 & 0.56 & 0.83 & 0.72 \\
$\mathbf{6}$ & 0.03 & 0.25 & 0.17 & 0.18 & 0.15 & 0.18 & 0.15 & 0.1 & 0.09 & 0.14 & 0.12 & 0.03 \\
Mean & 0.21 & 0.45 & 0.39 & 0.52 & 0.39 & 0.4 & 0.36 & 0.67 & 0.63 & 0.59 & 0.66 & 0.58
\end{tabular}


Tabel 2. Rata-Rata Nilai Serapan (Absorbansi/OD) pada Berbagai Kelompok Sesudah Inkubasi 24 Jam

\begin{tabular}{lccc}
\hline $\begin{array}{l}\text { Kelompok } \\
\text { Perlakuan }\end{array}$ & $\mathrm{N}$ & Mean & $\begin{array}{l}\text { Standar } \\
\text { Deviasi }\end{array}$ \\
\hline Kontrol & 6 & 0.6683 & 0.39862 \\
$\begin{array}{l}\text { EMDS 6.25 } \\
\mu \mathrm{g} / \mathrm{mL}\end{array}$ & 6 & 0.6317 & 0.38861 \\
$\begin{array}{l}\mathrm{EMDS} 12.5 \\
\mu \mathrm{g} / \mathrm{mL}\end{array}$ & 6 & 0.5867 & 0.36789 \\
$\begin{array}{l}\mathrm{EMDS} 25 \\
\mu \mathrm{g} / \mathrm{mL}\end{array}$ & 6 & 0.6667 & 0.41239 \\
$\begin{array}{l}\text { Doksorubisin } \\
\text { Total }\end{array}$ & 6 & 0.585 & 0.38025 \\
\hline & 30 & 0.6277 & 0.36387 \\
\hline
\end{tabular}

Hasil uji ANOVA menunjukkan terdapat kecenderungan penurunan ratarata nilai OD pada kelompok EMDS 6,25 $\mu \mathrm{g} / \mathrm{ml}$ dan kelompok EMDS $12,5 \mu \mathrm{g} / \mathrm{ml}$ dibandingkan kelompok kontrol tetapi meningkat kembali pada kelompok EMDS $25 \mu \mathrm{g} / \mathrm{ml}$ dengan OD yang hampir sama dengan kelompok kontrol tanpa perlakuan. Nilai OD pada kelompok pemberian Doksorubisin sebagai kelompok kontrol positif juga lebih rendah dibandingkan kelompok kontrol tanpa perlakuan. Walaupun demikian kecenderungan penurunan nilai $O D$ pada seluruh kelompok dibandingkan kelompok kontrol tanpa perlakuan tidak berbeda bermakna. (Gambar 1)

Dalam penelitian ini, meskipun hasil rerata pada berbagai kelompok menunjukkan peningkatan nilai OD sebelum dan sesudah diinkubasi selama 24 jam, yang berarti menunjukkan adanya peningkatan proliferasi/relatif viabilitas sel PC3, namun hasil rerata pada inkubasi sesudah 24 jam menunjukkan kecenderungan penurunan nilai OD pada kelompok EMDS $6,25 \mu \mathrm{g} / \mathrm{mL}$ dan kelompok EMDS 12,5 $\mu \mathrm{g} / \mathrm{mL}$ dibandingkan kelompok kontrol tetapi meningkat kembali pada kelompok EMDS $25 \mu \mathrm{g} / \mathrm{mL}$ dengan OD yang hampir sama dengan kelompok kontrol tanpa perlakuan. (Gambar 1) Ini diduga adanya efek sitotoksik dari senyawa aktif yang paling banyak terkandung dalam ekstrak daun sirsak yaitu asetogenin.

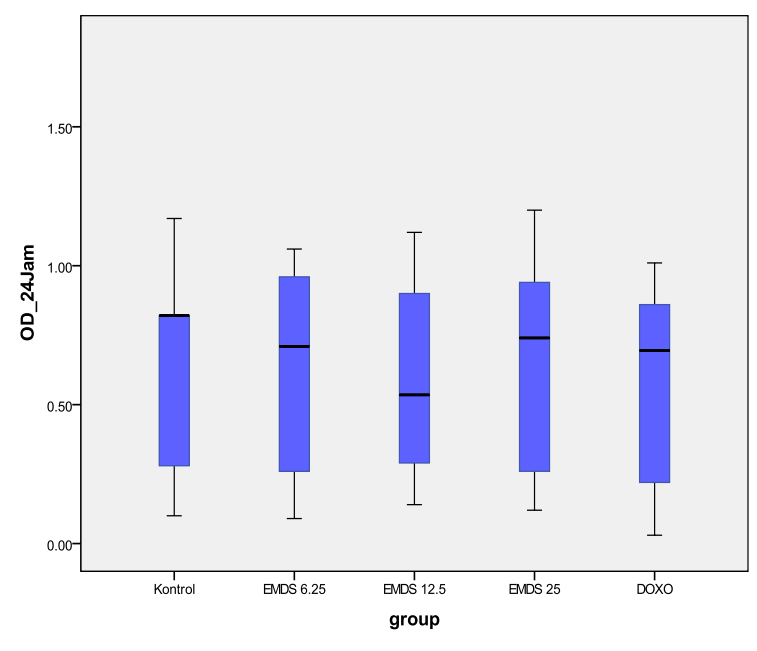

Anova test, $p=0.99$

Gambar 1. Grafik Perbandingan Nilai RataRata Absorbansi (OD) Antar Kelompok Perlakuan Setelah Inkubasi 24 Jam

Efek sitotoksik asetogenin diawali melalui proses difusi dari asetogenin ke dalam membran sel kemudian menghambat kompleks I rantai transport elektron di mitokondria melalui penghambatan NADH-ubiquinon oksidoreduktase. Enzim NADH bekerja pada transport elektron terminal pada saat Fe$S$ dan ubiquinon yang menyebabkan gradien proton antar membran yang diciptakan untuk reduksi pernafasan dari $\mathrm{O}_{2}$ ke $\mathrm{H}_{2} \mathrm{O}$ dihambat, sehingga mengakibatkan proses fosforilasi oksidatif di mitkondria terganggu yang kemudian berefek pada penurunan 
jumlah ATP yang dihasilkan. Akibatnya sel mengalami kekurangan energi untuk proses metabolismenya dan menyebabkan pertumbuhan sel terhambat sehingga sel mengalami apoptosis. ${ }^{11,12}$

Meskipun dalam penelitian ini hanya menggunakan ekstrak kasar bukan hasil isolasi kandungan dari daun sirsak, namun efek sitotoksik yang ditunjukkan diduga dapat berasal dari senyawa aktif asetogenin yang merupakan kandungan terpenting dalam daun sirsak atau senyawa lain yang terkandung dalam daun sirsak seperti flavonoid, tannin dan alkaloid yang juga memiliki efek antikanker. ${ }^{8}$

Kecenderungan penurunan yang tidak berbeda bermakna menunjukkan rendahnya aktivitas pada ekstrak metanol daun sirsak karena senyawa yang terkandung dalam ekstrak kasar tersebut beragam senyawa baik yang polar, semi polar maupun non polar sehingga efek toksiknya saling mempengaruhi.

Selanjutnya dengan mempertimbangkan bahwa proliferasi sel tidak sepenuhnya terhenti pada saat diinkubasi, maka dilakukan analisis untuk menilai apakah pemberian EMDS mempunyai efek dalam menghambat laju proliferasi dari 0 jam menuju 24 jam, penghitungan dilakukan dengan membandingkan selisih nilai absorban setelah 24 Jam dikurangi nilai absorban 0 Jam. Selisih nilai kenaikan pada masing-masing kelompok tertera pada Tabel.3

Untuk mengetahui apakah terdapat perbedaan nilai rerata peningkatan absorbansi dari 0 jam menuju 24 Jam masa inkubasi dilakukan analisis statistik ANOVA dan dilanjutkan dengan analisa
Posthoc yang hasilnya terlihat pada gambar 2.

Tabel 3. Peningkatan Rata-Rata Nilai Serapan (Absorbansi/OD) /
Kelompok (Nilai Dalam Bentuk Log) Dari Masa Inkubasi 0 Jam Sesudah Inkubasi 24 Jam

\begin{tabular}{lccc}
\hline $\begin{array}{l}\text { Kelompok } \\
\text { Perlakuan }\end{array}$ & $\mathrm{N}$ & Mean & $\begin{array}{c}\text { Std. } \\
\text { Deviation }\end{array}$ \\
\hline Kontrol & 6 & 1.07 & 0.26 \\
EMDS 6.25 & 6 & 1.09 & 0.32 \\
$\mu \mathrm{g} / \mathrm{mL}$ & & & \\
$\mathrm{EMDS} 12.5$ & 6 & 0.94 & 0.34 \\
$\mu \mathrm{g} / \mathrm{mL}$ & 6 & 1.12 & 0.26 \\
$\mathrm{EMDS} 25$ & 6 & 1.04 & 0.29 \\
$\mu \mathrm{g} / \mathrm{mL}$ & 30 & 1.05 & 0.29 \\
$\begin{array}{l}\text { Doksorubisin } \\
\text { Total }\end{array}$ & & & \\
\hline
\end{tabular}

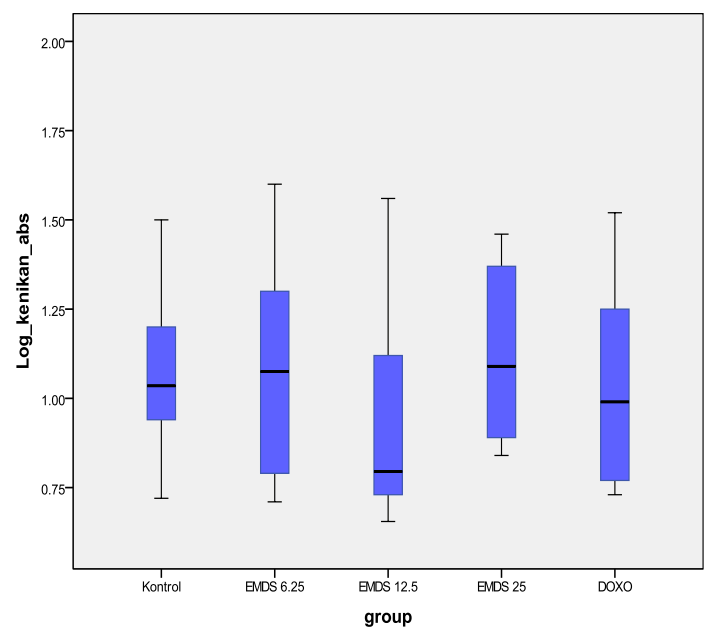

Anova test, $p=0.99$

Gambar 2. Grafik Perbandingan Kenaikan Nilai Rata-Rata Absorbansi (OD) Antar Kelompok Perlakuan dari Masa Inkubasi 0 Jam Sampai 24 Jam Inkubasi. 
Dari grafik tersebut tampak bahwa kenaikan rata-rata nilai absorbansi (OD) terendah terjadi pada kelompok EMDS $12,5 \mu \mathrm{g} / \mathrm{ml}$. Hal ini menunjukkan bahwa dosis tersebut mempunyai kemampuan menghambat viabilitas sel paling besar dibandingkan kelompok lainnya yang berarti bahwa konsentrasi tersebut merupakan konsentrasi optimal untuk mampu menghambat viabilitas sel PC3. Tetapi hasil tersebut tidak bermakna signifikan dan belum mencapai penghambatan sel sebesar $50 \%$.

Hasil tersebut berbeda dengan konsentrasi optimal yang didapat dalam penelitian Rachmani EPN dkk. ${ }^{20}$ yakni $17,149 \mu \mathrm{g} / \mathrm{mL}$. Konsentrasi optimal tersebut mampu menyebabkan apoptosis sel T47D secara signifikan. Hal ini diduga karena sel T47D termasuk sel hormonal dependen yang memiliki respon yang baik terhadap obat/zat antikanker dan prognosisnya juga lebih baik, ${ }^{21}$ berbeda dengan sel PC3 yang termasuk sel hormonal independen dan sel yang sangat metastatik atau agresif $^{18}$, sehingga dengan konsentrasi 6,25; 12,5 dan $25 \mu \mathrm{g} / \mathrm{mL}$ kurang memberikan respon secara signifikan, meskipun ada kecenderungan pada konsentrasi $12,5 \mu \mathrm{g} / \mathrm{mL}$ mampu menunjukkan penghambatan viabilitas sel PC3.

Kecenderungan penurunan viabilitas dari 6,25 dan $12,5 \mu \mathrm{g} / \mathrm{mL}$ namun meningkat kembali pada konsentrasi 25 $\mu \mathrm{g} / \mathrm{mL}$, hal ini berkaitan dengan semakin besar kadar sampel semakin panjang harga doubling time dan semakin kecil jumlah sel yang hidup. Hal ini disebabkan karena ekstrak metanol daun sirsak tidak cukup untuk membunuh semua sel sehingga sel yang masih hidup terus berproliferasi dan didukung tersedianya nutrisi dari media
RPMI 1640. Selain itu terkait juga dengan teori respon dosis, seperti penelitian yang dilakukan oleh Rahmawati dkk. ${ }^{22}$ dan Suyatmi dkk. ${ }^{23}$ yang menggunakan sel yang sama yakni sel HeLa, menunjukkan efek ekstrak daun sirsak berbeda. Pada penelitian Rahmawati dkk. ${ }^{22}$ dengan memakai 4 dosis ekstrak $(20,50,100,200 \mu \mathrm{g} / \mathrm{mL})$ didapatkan dosis optimal 111,75 $\mu \mathrm{g} / \mathrm{mL}$, sedangkan Suyatmi dkk. ${ }^{23}$ dengan 9 dosis $(10,20,30,50,100,150,200,300$ dan 500 $\mu \mathrm{g} / \mathrm{mL}$ ) didapatkan dosis optimal 97 $\mu \mathrm{g} / \mathrm{mL}$. Hal ini terkait dengan intensitas efek obat berbanding lurus dengan fraksi reseptor yang diikat dan fraksi reseptor tergantung pada beberapa hal diantaranya dosis dan lamanya paparan. Setelah fraksi reseptor semua sudah diduduki oleh obat maka peningkatan dosis tidak lagi menimbulkan respon yang terus meningkat tetapi membentuk kurva plateau/ mendatar. ${ }^{24}$ Pada penelitian ini, menunjukkan respon dosis, dimana terjadinya kecenderungan penurunan inhibisi pada konsentrasi 25 $\mu \mathrm{g} / \mathrm{mL}$ kemungkinan di konsentrasi 12 $\mu \mathrm{g} / \mathrm{mL}$ sudah merupakan batas optimal respon terhadap ekstrak.

Jika dilihat rerata nilai OD, pada konsentrasi $12,5 \mu \mathrm{g} / \mathrm{mL}(0,58)$ memiliki nilai OD sedikit lebih rendah dengan doksorubisin $(0,59)$. Ini menunjukkan bahwa dosis doksorubisin yang digunakan belum cukup mampu menghambat sel PC3 secara signifikan karena sel PC3 sebagai sel yang metastatik dan independen hormonal sangat resisten terhadap doksorubisin. Hal ini berbeda dengan dosis doksorubisin sebesar 15 $\mu \mathrm{g} / \mathrm{mL}$ yang disadur dari penelitian yang dilakukan Titiek $S$ dkk. ${ }^{25}$ menggunakan senyawa alkaloid mahkota dewa (Phaleria macocarpa) pada sel T47D 
me-nunjukkan efek sitotoksik yang signifikan pada dosis optimal sebesar $11,14 \mu \mathrm{g} / \mathrm{mL}$.

Selain melakukan uji viabilitas dengan teknik MTT, pengamatan juga dilakukan terhadap perubahan morfologi sel PC3 setelah pemberian ekstrak metanol daun sirsak selama inkubasi 24 jam. Hasil pengamatan dapat dilihat pada Gambar 3

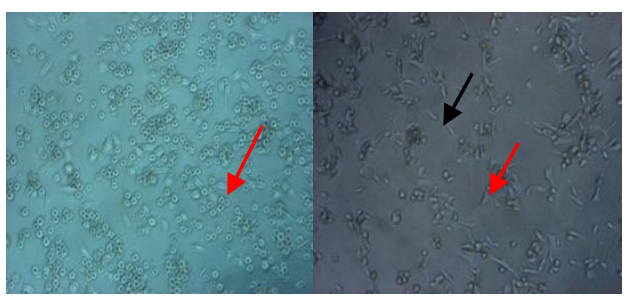

A

B

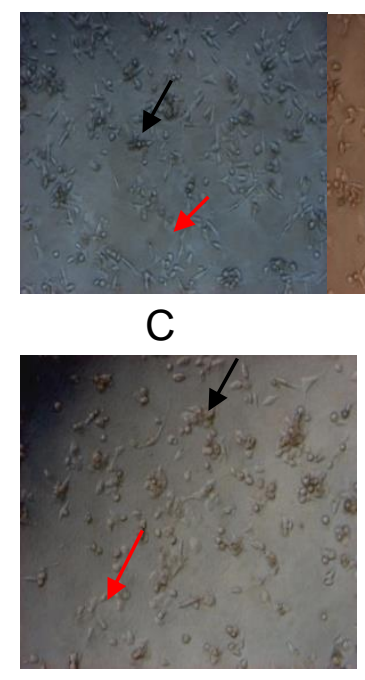

E

Gambar 3.Gambaran Morfologi Sel PC3.

Keterangan: A. Kontrol Sel PC3 setelah inkubasi 24 jam B. Sel PC3 dengan perlakuan ekstrak metanol daun sirsak pada konsentrasi $6,25 \mu \mathrm{g} / \mathrm{ml}$ (B), $12,5 \mu \mathrm{g} / \mathrm{ml}(\mathrm{C}), 25 \mu \mathrm{g} / \mathrm{ml}$ (D) dan Sel PC3 dengan permberian doksorubisin (E) (sel hidup: $\longleftarrow$, sel mati:

\section{$\longleftrightarrow$}

Hasil pengamatan morfolgi sel PC3 dilakukan untuk mengetahui efek sitotoksik ekstrak metanol daun sirsak. Jika dilihat di bawah mikroskop, morfologi sel antara sel PC3 yang hidup dan mati menunjukkan perbedaan. Pada kelompok kontrol sel (Gambar 3.A), semua sel menunjukkan morfologi sel hidup. Sel hidup akan berwarna terang karena terdapat cairan sitoplasma yang dapat meneruskan cahaya dari mikroskop dan berbentuk agak panjang. Pada perlakuan senyawa uji pada konsentrasi tertinggi (25 $\mu \mathrm{g} / \mathrm{ml})$ menunjukkan morfologi sel sedikit mengalami kematian (Gambar 3.D). Sel yang mati akan terlihat gelap dan berbentuk bulat. Hal ini terjadi karena sel kehilangan sitoplasma akibat rusaknya membran sel, sehingga sel tidak dapat meneruskan cahaya dari mikroskop. Pada konsentrasi terendah $(6,25 \mu \mathrm{g} / \mathrm{ml})$ masih banyak sel hidup, hal ini menunjukkan bahwa ekstrak metanol daun sirsak kurang mampu mempengaruhi kematian sel PC3 (Gambar 3.B).

Sel yang mati dapat merupakan proses apoptosis ataupun nekrosis. Karena menurut Villo, senyawa asetogenin yang bersifat sitotoksik mampu menghambat ikatan NADH oksidase ubiquinon pada membran sel kanker yang menyebabkan sel kekurangan ATP dan berakibat kematian sel. Adanya sinyal positif intrasel akibat kekurangan ATP menyebabkan perubahan pada pori membran mito-kondria sehingga menjadi permeabel dan dilepaskannya kelompok protein proapoptotik kedalam sitosol yaitu Bax atau Bad yang menginduksi pelepasan sitokrom-c yang selanjutnya dapat mengaktivasi jalur cascadecaspase. ${ }^{11}$ Ini sesuai dengan penelitian yang dilakukan oleh Yuan SSF dkk. ${ }^{19}$ yang menunjukkan kerja turunan asetogenin squamocin yang mampu menghambat proliferasi sel kanker pada fase $G_{1}$ dan meningkatkan ekspresi protein Bax dan Bad serta mampu 
meningkatkan ekspresi p21. Liang dkk 26 juga membuktikan efek squamocin yang mampu memicu mitokondria melepaskan sitokrom-c dan mengaktivasi caspase cascade.

Perubahan karakteristik morfologi galur sel kanker prostat PC3 dari hasil kultur, terlihat galur sel PC3 melekat pada dasar wadah (flask). Galur sel PC3 termasuk tipe cell lineadherent (sel monolayer). Sel monolayer dengan bentuk seperti sel epitel/ pipih, membentuk kelompok dan dapat beradaptasi dengan medium suspensi pertumbuhan. Sel PC3 juga termasuk dalam sel transformed yakni sel yang memiliki kemampuan untuk tumbuh tidak terbatas dalam kultur dan biasanya sel tersebut berasal dari sel tumor. Kelebihan dari pertumbuhan yang menempel adalah kemampuan dari sel untuk menempel dan menyebar pada permukaan. Hal ini memudahkan dalam pengujian mikroskop, hibridasi dan pengujian fungsional lainnya. ${ }^{18}$

\section{SIMPULAN}

Terdapat kecenderungan penurunan viabilitas galur sel kanker prostat PC3 setelah pemberian ekstrak metanol daun sirsak pada inkubasi 24 jam. Ekstrak metanol daun sirsak pada konsentrasi 6,25; 12,5 dan $25 \mu \mathrm{g} / \mathrm{mL}$ tidak menghasilkan perbedaan penurunan viabilitas secara signifikan tetapi terdapat kecenderungan efek sitotoksik optimal terjadi pada konsentrasi 12,5 $\mu \mathrm{g} / \mathrm{mL}$.

\section{DAFTAR RUJUKAN}

1. Cancer Research UK. Cancer worldwide-the global picture. 2013 [cited 2013_ 29 March].Available from:http://www.cancerresearchuk.org/canc er-info/cancerstats/world/the-global-picture/.
2. GLOBOCAN. All Cancer Incidence and Mortality World-wide in 2008. 2011 [cited 201128 September]. Available from: http: //globocan. iarc.fr/factsheet.asp\#MEN.

3. Departemen Kesehatan RI. Riset Kesehatan Dasar, Depkes RI. Jakarta. 2007

4. Umbas R. Penanganan Kanker Prostat Stadium II pada penderita berusia 70 tahun atau labih: Pengalaman dua rumah sakit tertier di Jakarta. Indonesian J Cancer. 2009;11(4):133-5

5. Robbins and Cotran.Pocket Com-panion to Pathologic Basis of Disease. Ed. $7^{\text {th }}$. Philadelphia PA: Saunders Elsevier. 2010:15-17,172-4,177-9,202

6. Carelle NR, Piotto E, Bellanger A, Germanaud J, Thuillier A, Khayat D. Changing Patient Per-ceptions of The Side Effects of Cancer Chemotherapy. Cancer.2002 July;95(1):155-63

7. World Health Organization. Traditional Medicine Strategy 2002-2005. WHO; 2012. [cited 201228 September].Available from: http://www.who.int/medicine/organization/tr m/orgtrmmain.shtml.

8. Adewole SO dan Ojewole JAO. Protective Effects of Annona muricata Linn, (annonaceae) Leaf Aqueous Extract on Serum Lipid Profiles and Oxidative Stress in Hepatocytes of Streptozotocin-Treated Diabetic Rats, Aft. J. Trad Cam. 2009;6(1):30-41

9. Baskar R, Rajeswari V, KumarTS. In Vitro Antioxidant Studies In Leaves of Annona Species. Indian J. Exp. Biol.2007;45:480-85

10. Yuan SSF, Chang HL, Chen HW dkk. Annonacin, A mono-tetra-hydrofuran Acetogenin, Arrests Cancer Cells at the G1 phase and Cause Cytotoxicity in a Bax- and Caspase-3 Related Pathway. J. Life Sci. 2003;72:2853-61

11. Villo P. Synthesis of Acetogenin Analogues, Thesis, University of Tartu Faculty of Science and Technology Institute of Technolo-gy, Tartu.2008

12. McLaughlin JL. Paw-paw and cancer: Annonaceous Acetogenins from Discovery to Commercial Products. J.Nat.Prod. 2008;71:1311-21

13. Pamungkas AR.Efek Sitotoksik dan Induksi Apoptosis Ekstrak Metanol Daun Sirsak 
(Annona muricata) pada Sel Kanker Payudara T47D, Skripsi, Fakultas Kedokteran dan IImu-ilmu Kese-hatan, Universitas Jenderal Soedirman, Purwokerto.2011

14. Morgan SJ, Darling DC. Animal Cell Cultur. BIOS Scientific Publishers.1993:7-19,2746,76-77

15. Mosmann. Rapid Colorimetric Assay for Cellular Growth and Survival: Application to Prolifera-tion and Cytotoxicity Assays. J. Immunol.Methods. 1983;65 (1-2):55-63

16. Dahlan $M$ dan Sopiyudin. Statis-tik untuk Kedokteran dan Keseha-tan. Edisi 4. Salemba Medika, Jakarta. 2006

17. Subowo. Biologi Sel. Edisi Keenam. Sagung Seto.2011:396-7

18. American Type Culture Collec-tion(ATCC) CRL-1435. Thawing, Propagating and Cryopreserving Protocol: NCl-PBCFCRL1435 (PC-3) Prostate Adenocarcinoma. Physcal Science Oncology Cenert Facility. 2012; Version 1.5

19. Yuan SSF, Chang HL, Chen HW dkk. Selective Cytotoxicity of Squamocin on T24 Bladder Cancer Cells at The S-Phase Via a Bax-, Bad-, and Caspase-3-related Pathway. J.Life Sci.2006;78:869-874.

20. Rachmani EPN, Suhesti TS, Widiastuti R, dan Aditiyono. The Breast of Anticancer from Leaf Extract of Annona muricataAgaints Cell Line in T47D. Int.J. Appl. Sci.Technol. 2012;2(1):157-64
21. Duan R, Ginsburg E, and Vonderhaar BK. Estrogen Stimu-lates Transcription from The Human Prolactin Distal Promoter Through AP1 and Estrogen Responsive Elements in T47D Human Breast Cancer Cells. Mol.Cell. Endocrinol. 2008;281:9-18

22. Rahmawati A. Aktivitas Antibakteri Ekstrak Etanolik Buah Sirsak (Annona muricata) Terhadap Pertumbuhan Bakteri Staphylococcus aureus dan Escherichia coli. Skripsi, Fakultas Kedokteran dan IImuilmu Kesehatan Universitas Soedirman, Purwokerto. 2010

23. Suyatmin, Suselo $\mathrm{YH}$, Jusuf SA. The Selective Cytotoxicity of Ethanolic Extract of Annona muricata leaf on HeLa Cervical Cancer Cells. International Conference: Research and Appli-cation on Tradisional Comple-mentary and Alternative Medicine in Health Care (TCAM). Surakarta, Indonesia. 2012

24. Eaton DL and Gilbert SG. Princi-ples of Toxicology in: Casarett \& Doulls Toxicology: The Basic Science of Poisons. Seventh edition. Classen CD (editor). McGrawHill.New York.2008:11-23

25. Sumarawati $T$ dan Famawati $D$. Isolasi dan uji Sitotoksik Senyawa Alkaloid Mahkota Dewa (Phaleria macocarpa) pada Kultur Sel Kanker Payudara (T47D). Prosiding Seminar Nasional For Cancer. FK Unisula. Semarang.2011:102-10

26. Liang YJ. Bullatacin Triggered ABCBIOverexpressing Cell Apoptosis via The Mitochondrial-Dependent Pathway, J.Biomed.Biotechnol. 2009 